\title{
Fault Detection Technique for Hierarchical Monitoring of Steel Making Facilities Based on Data Science
}

\author{
Takehide Hirata ${ }^{1)^{*}}$, Masafumi Matsushita ${ }^{1)}$, Yukinori IrzukA ${ }^{1)}$ and Noritsugu Suzuki ${ }^{2)}$ \\ 1) Steel Research Laboratory, JFE Steel Corporation \\ 2) Plant Engineering Technology Department, JFE Steel Corporation
}

Abstract: In steel making processes, influence of an equipment fault on production operation is significant. It is strongly required to detect an equipment fault at an early stage and to prevent the damage. Therefore, fault detection technique for steel making facilities based on data science is developed as an online-monitoring system. One of main features of the developed system is hierarchical monitoring consisting of three levels such as an entire process, facilities and sensors. Another is display of heat-mapping according to the degree of anomaly for huge number of monitoring items. Some anomaly signs at the hot rolling process where the system has been developed are successfully detected.

Keywords: anomaly detection; Lasso regression; principal component analysis; data-driven; deep-learning.

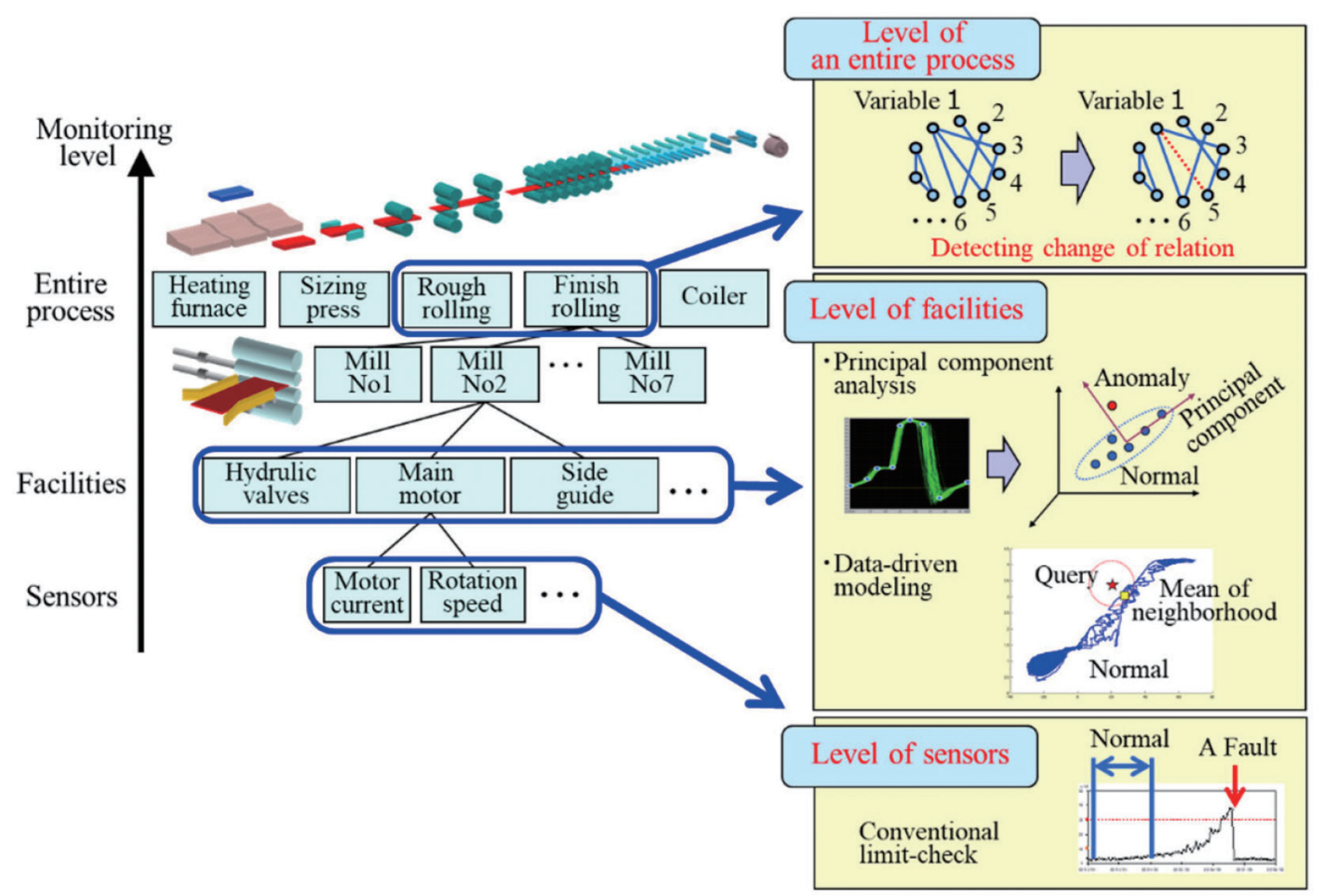




\title{
データサイエンスに基づく鉄鋼プロセス設備の レベル別異常予兆検知技術
}

\author{
平田 丈英 ${ }^{1{ }^{*}}$ ・松下 昌史 ${ }^{1)} \cdot$ 飯塚 幸理 ${ }^{1)} \cdot$ 鈴木 宣嗣 $^{2)}$
}

Fault Detection Technique for Hierarchical Monitoring of Steel Making Facilities Based on Data Science

Takehide Hirata, Masafumi Matsushita, Yukinori IrzuKa and Noritsugu Suzuki

\section{1. 緒言}

鉄鋼プロセスは，製銑，製鋼，圧延などのプロセスが連 関しており，各工程を構成する設備が 1 つでも故障すると 次工程以降への影響が甚大である。そのため，設備異常の 予兆を早期に発見しトラブルを未然に防止し安定操業を行 なわなければならない。しかし，監視すべき設備数が非常 に多く，設備種類も多岐に渡るため，発生したトラブル事 例に基づき個々に監視ロジックを構築する従来の方法では 限界がある。

従来の設備異常監視は, 圧延機の駆動系を始めとする回 転機械系を対象とした振動計による監視 ${ }^{1-3)}$ が主流である。 その他に，圧延機の圧下系などの油圧サーボ系を対象に制 御手法を適用した監視 ${ }^{4,5)}$ や鋼材を搬送するテーブルロー ルを対象としたモータ負荷電流 ${ }^{6,7)}$ による監視など機器別 の監視などの報告がある。いずれも特定の機器を対象とし ており，限定的，局部的な監視に留まっている。

そこで, これらの問題を解決するために, 大量の操業 データに対してデータサイエンス技術を適用し，網羅的， かつ，高精度な監視を両立可能な設備異常予兆監視技術を 開発しシステムとして構築した7)。

本論文では，熱間圧延工場での検知事例を交えて，開発 したシステム扎よび監視手法について述べる。また，プロ セス全体レベルの監視を対象に，新たに開発した異常の発 生源を絞り込む $\mathrm{AI}$ 技術についても述べる。

\section{2. システムの概要}

鉄鋼プロセスの特徵は, 多種多様な機器や設備から構成 され，さらに階層的な構造を示す点にある。そこで, Fig.1 に示すように, プロセス全体, 機器, 計器のレベル別監視 を構成し，各レベルに適切な手法を適用した。レベル別の 監視は，プロセス全体の絡み合う現象からの視点，プロセ
スを構成する機器の動作からの視点といった異なる視点 での監視となるため, 網羅的, かつ, 高精度な監視が可能 となる。下位の計器レベルは従来の上下限チェックで対応 できる監視である。中位の機器レベルは機器単独の動作 異常を検知する監視である。機器レベルでは, 主成分分析 (Principal Component Analysis，以下PCA）を用いた波形監 視 ${ }^{6-8)}$ と, データ駆動型モデルを用いた変数間相関監視 ${ }^{6,7,9)}$ を主要な監視手法として導入した。開発した 2 手法は高い 汎用性と高い検知精度を両立するため, これまで監視が難 しかった多数の設備への監視拡大を可能にすることがで きた。上位の全体レベルは，プロセスの主要な現象 (熱間 圧延の場合, 圧延現象) の正常時からの相関崩れを検知す る監視である。全体レベルでは, 扱う操業変数項目が百以 上と膨大になるため, ビッグデータ解析に有利なスパース モデリングの一種であるLasso回帰に基づく手法を導入し た ${ }^{7)}$ 。本手法は, 収集可能な操業データすべてを対象に容 易にモデルを構築することができるので, 網羅的な監視が 可能となる。いずれのレベルの場合も正常時の基準に対す る外れ度合いを異常度として指標化した。

本システムのもう1つの大きな特徴として, 対象とする 監視項目が膨大な数となるため, 網羅的かつ効率的に監視 するために，監視項目別の異常度の経時変化を，その大き さに応じてヒートマップ表示する点である。表示例を Fig.2 に示す。縦軸は監視対象の項目, 横軸は圧延順であり, 1 つ のセルは圧延材毎に統計演算した異常度 (平均值や最大值 などの統計量) を示す。

モデルは，鋼種，サイズ，設備動作モードなどにより区 分化しているが，モデル間で感度に違いがあると，実異常 の傾向変化を捉えにくくなるため, 異常度の尺度を統一す る工夫を行った。本システムの概要を Fig. 3 に示す。異常度 の演算は圧延完了時に一括処理され, ヒートマップ表示画 面が更新される。ヒートマップ表示画面は操作室や事務所 などでWeb閲覧可能である。また，監視モデルを通して着 
目すべき変数 (説明変数など) が特定されるので必要に応 じて散布図などのグラフの自動作成も可能である。散布図 では，正常材とトラブル材の比較を容易に行うことができ るため，異常発生時には，事務所で一次解析まで行うこと が可能となる。

\section{3. 全体レベルの監視}

熱間圧延プロセスの全体レベルの監視に適用したLasso 回帰の概要について述べる。全体レベルの監視の狙いは, 圧延現象の相関崩れから設備異常を検知することである。 Lasso 回帰では微小な影響係数がゼロとなり不要な説明変 数を大幅に削減できるため, ビッグデータ解析に適した手 法の 1 つである。また, 回州式であるため, 異常検知時に要 因元となる変数の特定が比較的容易である。回帰係数の演 算手法がいくつか報告されている中で ${ }^{10-13)}$, 本報告で採用 したベーシックな回帰係数の演算式を以下に示す。

To minimize $\sum_{i=1}^{N}\left(y_{i}-\sum_{j=1}^{P} x_{i j} a_{j}\right)^{2}+\lambda \sum_{j=1}^{P}\left\|a_{j}\right\|$

$y:$ 目的変数, $x:$ 説明変数, $a:$ 回帰係数,

$N:$ データ数, $P:$ 変数項目数, $\lambda:$ 重み
式（1）により正常時の全操業変数のデータを用いて回帰 式を構築する。熱間圧延プロセスの場合, 具体的な変数は 圧延荷重, 圧下位置, 圧延機モ一夕電流, 圧延速度, 圧延機 スタンド間張力などがあり, 各々が目的変数であり, 互い の説明変数でもある。また, 動特性も考慮し, 同時刻の変 数だけでなく過去の変数も扱うため, 例えば, 100 個の操 業変数に対して, 1 操業変数あたり 10 個の時間展開項とす ると, 実際には 1000 項目の規模となる。このような数多く の変数を扱う熱間圧延へのLassoの適用は本報告が初めて である。

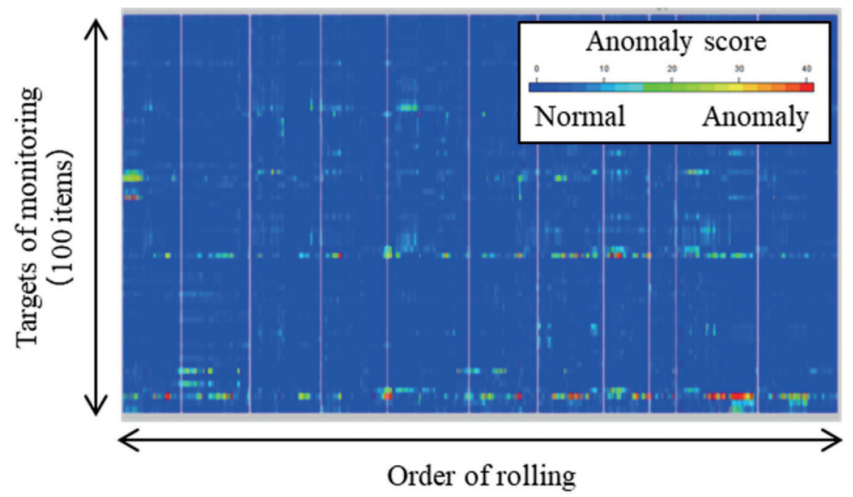

Fig. 2. Example of heat-mapping display. (Online version in color.)

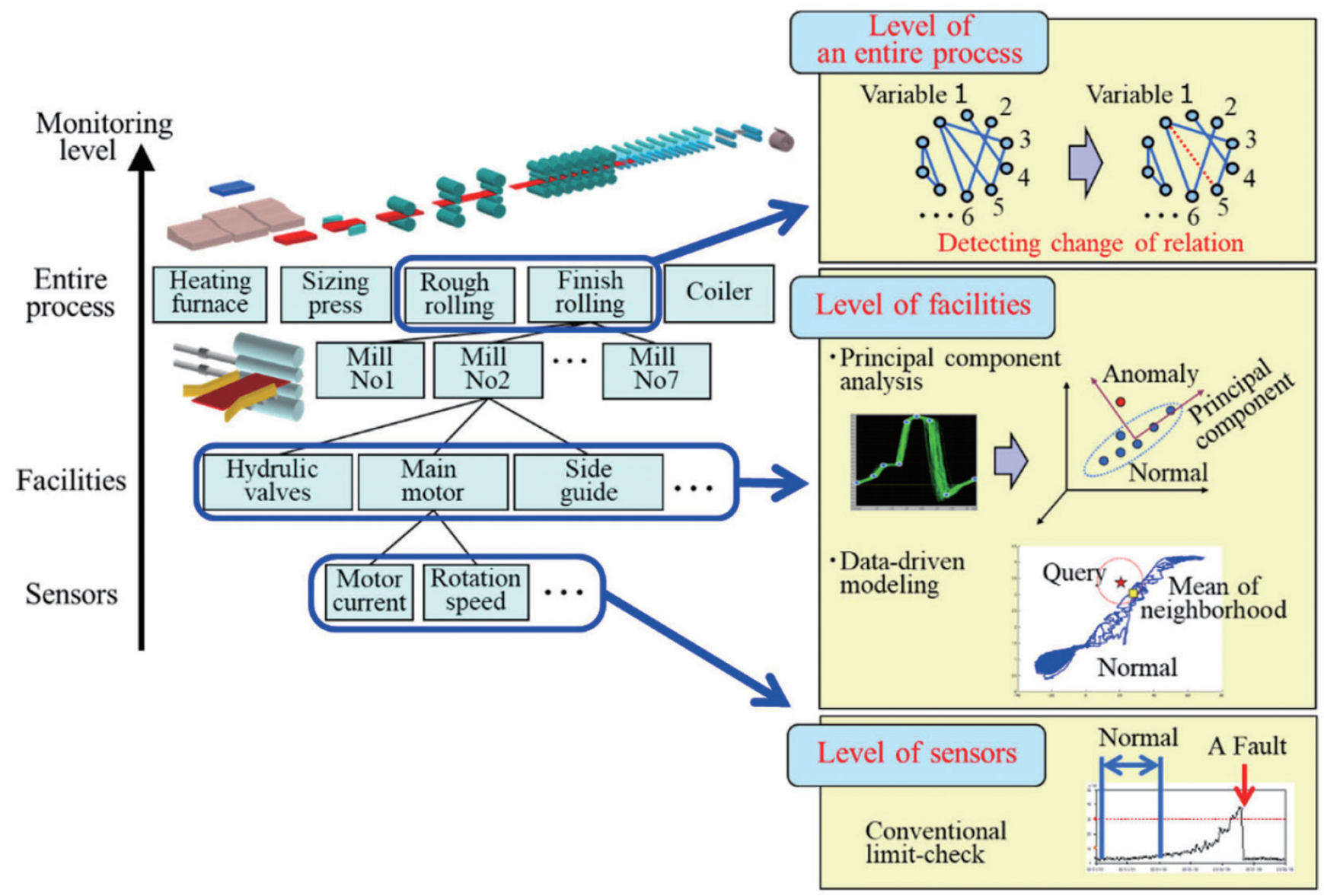

Fig. 1. Concept of anomaly signs detection by hierarchy level of a manufacturing process. (Online version in color.) 
説明を容易にするために6変数を対象とした場合の例を Fig.4に示す。変数間を結合する線は変数間に相関があるこ とを示す。(a) は正常時の関係であり，式（1）により，困に 示される6個の回帰式が構築される。この例では，互いに 独立する2つのモデルが混在するが，陽に扱うことなく適 切にモデルが構築されると考えられる。一方，(b) は異常 時の関係であり， $x_{2}$ と $x_{4}$ の相関が崩れた場合を示す。(a)の 正常な関係があるときに，予め準備した正常時のデータに 対して変数別の予測モデルを構築し，監視判定したい(b) のような事例に対して，新たに得られる実績值から予測䛊 差を演算する。判定対象のデータが正常であれば予測誤差 は小さく，(b) の事例のように異常であれば予測誤差は大 きくなるため，予測誤差に基づき変数別に異常度を演算す ることができる。

$$
S_{y_{i}}=f\left(\frac{e_{i}}{\sigma_{e_{i}}}\right), e_{i}=y_{i}-\hat{y}_{i}
$$

$S_{y i}:$ 変数 $y_{i}$ の異常度

$e_{i}:$ 数 $y_{i}$ の予测䛊差

$\sigma_{e i}$ : 変数 $y_{i}$ の予測誤差の正常時における標準偏差

熱間圧延工場での予兆検知の例を Fig.5 に示す。図に示 すのは圧延機の状態を示す指標（変数A）に対する異常度 のチャートである。上昇傾向にあった異常度が補修後に低 下しているのが確認できる。このとき変数Aの予測モデル として選択された説明変数をFig.6に示す。影響係数の大 きい順に5つ示してある。このモデルの特徵は同一圧延機 の状態を示す変数 B,Cが選択されていることである。すな わち，単一圧延機内でのある特定の圧延現象がモデルとし て構築されている。同一圧延機の変数 $\mathrm{A}$ と変数 $\mathrm{B}$ の関係を Fig.7に示す。どちらも実績值である。水色のプロットは正 常時の関係でありモデル構築に用いた学習データである。 これに対して黄色〜赤色のプロットはアラーム発報のあっ た材から4本前までの実績值である。困で示されるように
正常時の関係から変数 Aが逸脱し, 圧延現象の相関が崩れ たことにより異常度が上昇したことがわかる。

別の事例を Fig.8に示す。困に示すのは圧延機の状態を 示す指標 (変数C) に対する異常度のチャートである。こ の事例も異常度が上昇傾向にあることが確認できる。な お，図では示されてないが，この後の補修により異常度は 上昇前のレベルまで低下した。前述の事例と同様に変数 C の予測モデルとして選択された説明変数を Fig.9に示す。 このモデルの特徴は異なる圧延機の同一変数 Cが選択され ていることである。すなわち, 圧延機間の変数Cのバラン スがモデルとして構築されている。2つの圧延機間の変数 Cの関係を Fig.10に示す。罒の見方は前述の事例と同様で ある。罒で示されるように変数 Cが正常時の関係から逸脱 し, 圧延機間のバランスが崩れたことにより異常度が上昇 したことがわかる。

以上のことから Lasso回帰により圧延現象や圧延機間の バランスが適切にモデル化され，異常の予兆が検知されて

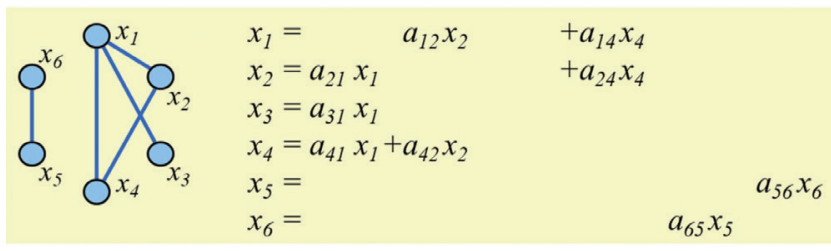

(a) normal operation

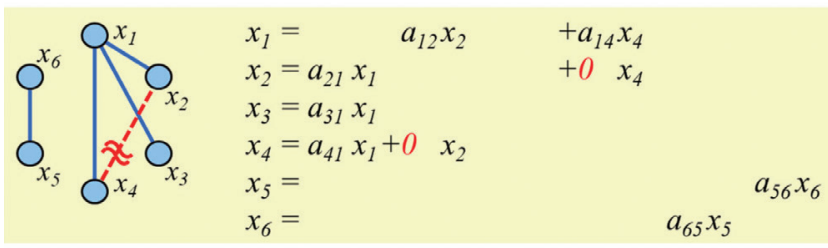

(b) anomaly operation

Fig. 4. Application of Lasso regression method to detecting anomaly signs of the entire process. (Online version in color.)

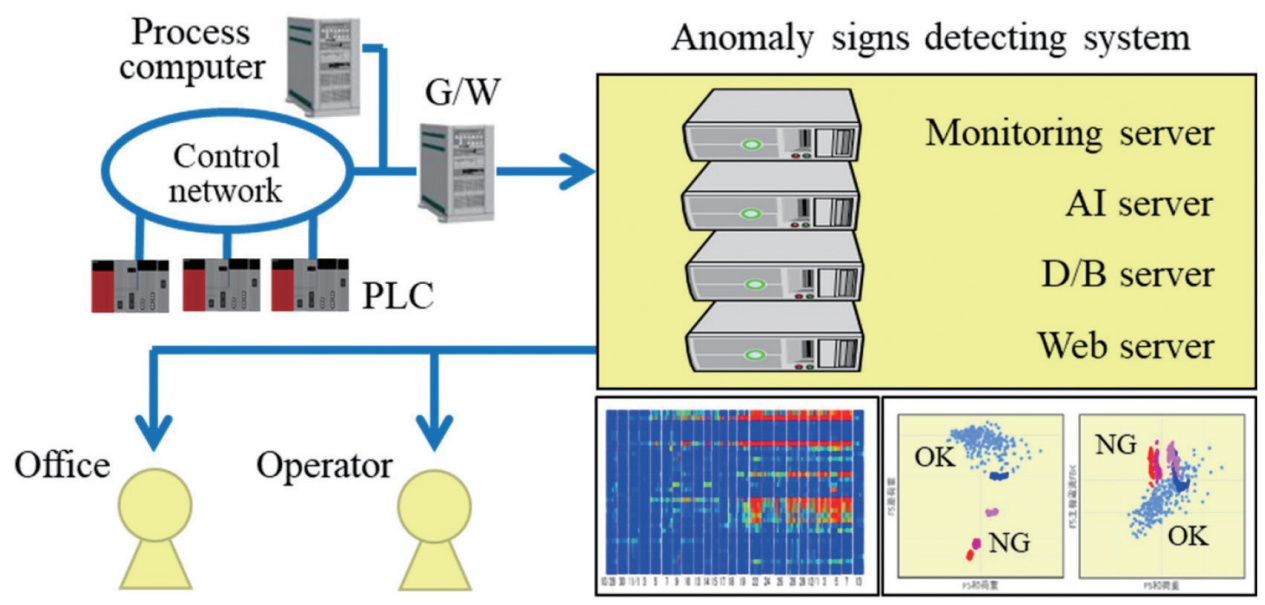

Fig. 3. System configuration of anomaly signs detection. (Online version in color.) 
いることがわかる。

\section{4. 機器レベルの監視}

機器レベルの監視には，PCAを用いた波形監視と，デー タ駆動型モデルを用いた変数間相関監視を主要な監視手法 として開発した。機器レベルの監視の狙いは, 機器単独の 動作異常を監視することである。この2つの手法の開発に

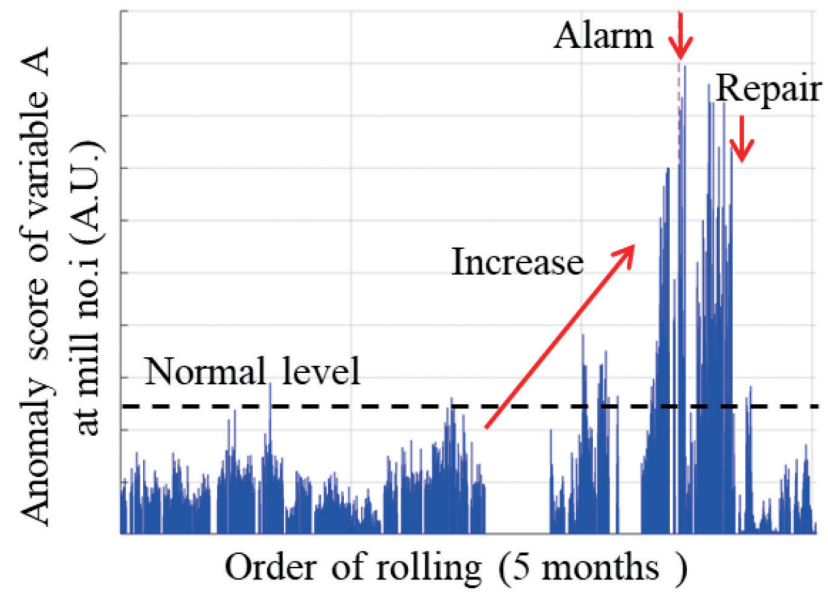

Fig. 5. Example of detecting anomaly signs by the level of the entire process. (Online version in color.)

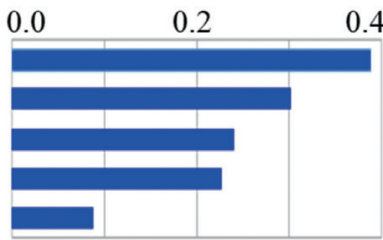

Other variable at the other mill

Variable B at the same mill

Variable $\mathrm{C}$ at the same mill

Other variable at the other mill

Other variable at the other mill

Fig. 6. Coefficient of the explanatory variables of model A. (Online version in color.)

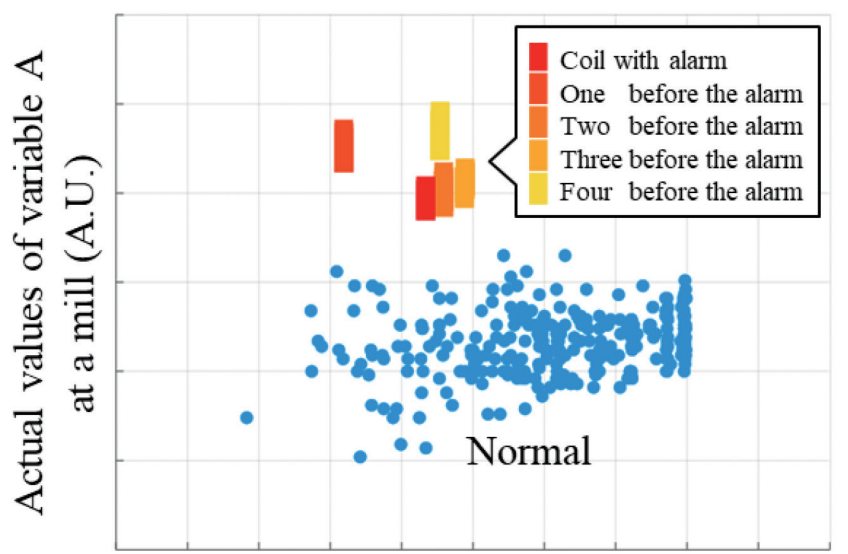

Actual values of variable $B$ at the same mill (A.U.)

Fig. 7. Comparison between the Alarm coil and the normal coils in relationship between variable $\mathrm{A}$ and $\mathrm{B}$ at the same mill. (Online version in color.)
より，これまで監視が難しかった設備について，汎用的か

つ大量に監視対象を拡大することが可能となる。

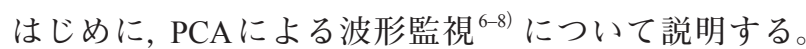
$\mathrm{PCA}^{14,15)}$ の適用としては操業変数間の相関崩れに着目した 異常検知への適用 ${ }^{16,17)}$ が主流であるが，本報告ではこれら と異なる適用となる。一定の繰り返し動作を示す設備は, その設備の状態を示す信号の波形が一定であり，異常時に は波形が乱れることが多い。そこで，PCAを用いて異常初

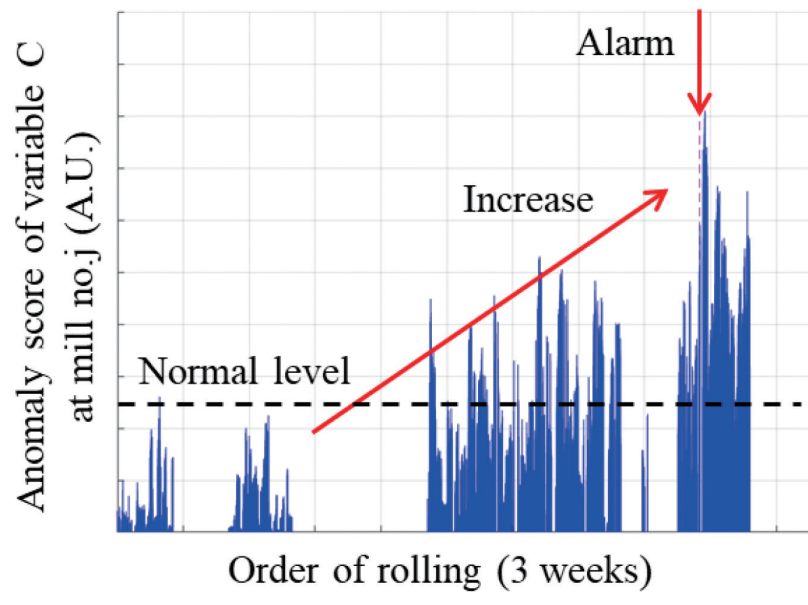

Fig. 8. Example of detecting anomaly signs by the level of the entire process. (Online version in color.)

Variable $\mathrm{C}$ at the other mill Variable $\mathrm{C}$ at the other mill Other variable at the other mill Variable $\mathrm{C}$ at the other mill Other variable at the other mill

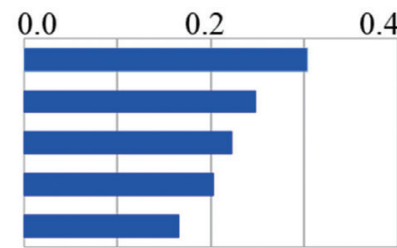

Fig. 9. Coefficient of the explanatory variables of model C. (Online version in color.)

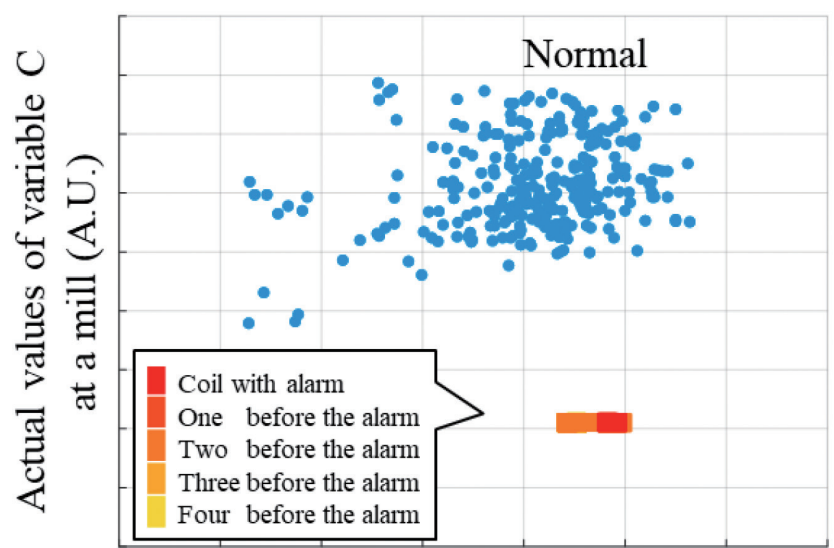

Actual values of variable $\mathrm{C}$ at the defferent mill (A.U.)

Fig. 10. Comparison between the Alarm coil and the normal coils in relationship of variable $\mathrm{C}$ between two mills. (Online version in color.) 
期の波形の乱れを検知する方法を開発した。一定の繰り返 し動作を示す典型的な設備としては位置決めモータの動作 などがある。Fig.11は位置決めモータで駆動される設備の 移動量の波形を示した図である。

波形を構成するサンプリング点が $P$ 点あるとすると, 1 つの波形は $P$ 次元空間上では 1 点に対応する。隣り合う专 ンプリング点は相関があるため, 正常時の波形は $P$ 次元空 間上で互いに相関を有する形で分布する。ここでPCAを適 用することで，正常時の波形を主成分として抽出すること が可能となる。罒に示すように，ハンチングなどにより波 形に乱れが生じるときは主成分から外れるので，主成分に 垂直な成分として定義される逸脱度を算出し，監視するこ とで異常予兆を検知できる。この手法は, 設備の種類を問 わず，正常時の波形のばらつきは異常として検知されにく い一方で, 設備起因の微小異常は検知しやすいという特徵 がある。計算式を以下に示す ${ }^{8,9}$ 。 $T^{2}$ 統計量は主成分方向の 指標， $Q$ 統計量は主成分に垂直な方向の指標である。

$$
T^{2}=\sum_{r=1}^{R} \frac{t_{r}^{2}}{\sigma_{t r}^{2}} Q=\sum_{p=1}^{P}\left(x_{p}-\widehat{x}_{p}\right)^{2}
$$

$t_{r}:$ 第 $r$ 主成分得点

$\sigma_{t r}:$ 第 $r$ 主成分得点 $t_{r}$ の標準偏差

$x_{p}: \mathrm{p}$ 番目にサンプリングされたデータ(ハットはPCA による再構築データ)

$R:$ 主成分数 (次元圧縮後の次元)

$P$ : データサンプリング数

次に,データ駆動型モデルを用いた変数間相関監視 $6.7,9)$ について説明する。データ駆動型モデルの適用としては各 種予測モデルへの適用 ${ }^{18-21)}$ が主流であるが，本報告ではこ

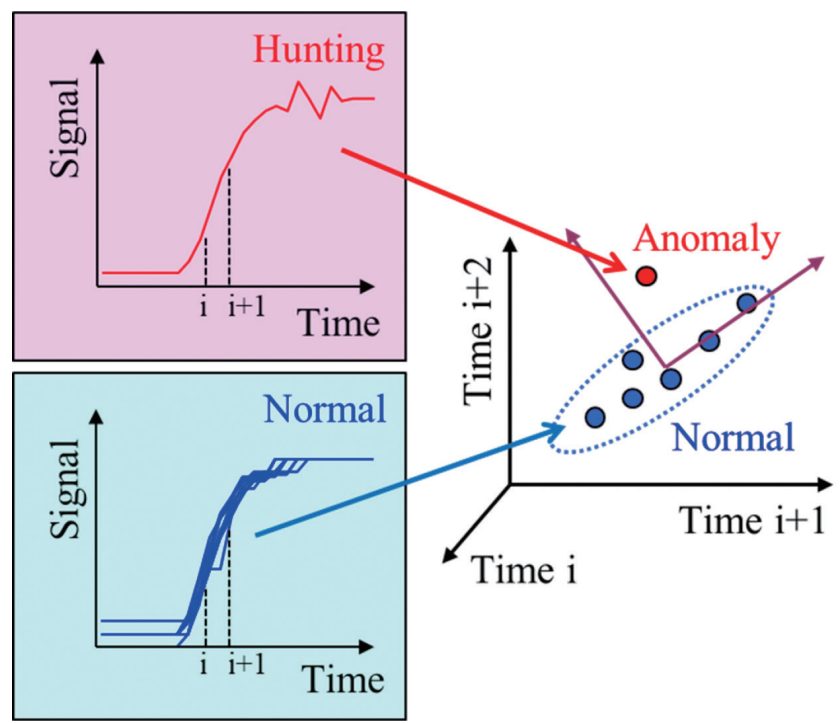

Fig. 11. Application of PCA method to detecting anomaly signs in a facility. (Online version in color.)
れらとは異なる適用となる。Fig.12で示すように，正常時 の設備状態を示す変数間に一定の相関がある場合に, 過去 の正常実績をデータベースに事前登録し, 判定対象の計測 值を取得したときに, 判定対象とデータベースに事前登録 したデータ間との距離を求める。次に距離順に所定数を近 傍データとして抽出し重心を求める。判定対象と重心間の 距離が大きければ正常時のデータ分布から外れることにな るので, 判定対象と重心間の距離を冕脱度として定義し監 視することができる。この手法は変数間に強い非線形性が ある場合や正常時のばらつきが大きい場合でも，設備の種 類を問わず汎用的に適用できるという特徵がある。判定対 象と重心間の距離 $d_{a}$ の計算式を以下に示す。

$$
\begin{aligned}
d_{a} & =\sum_{i=1}^{k} d_{i} / k, d_{i}=\sqrt{\sum_{i=j}^{p}\left(x_{j}-q_{j}\right)^{2}} \\
k & : \text { 近傍データ数 } \\
p & : \text { データ項目数 } \\
x_{j} & : \text { 近傍データに対する変数 } j \\
q_{j} & : \text { 判定データに対する変数 } j
\end{aligned}
$$

予兆検知の例として, 仕上巻取機における巻取開始直後 の設備動作に対するPCAを用いた波形監視およびデータ 駆動型モデルを用いた相関監視の結果例を Fig.13に示す。 どちらも上昇傾向にあった異常度が補修後に低下している
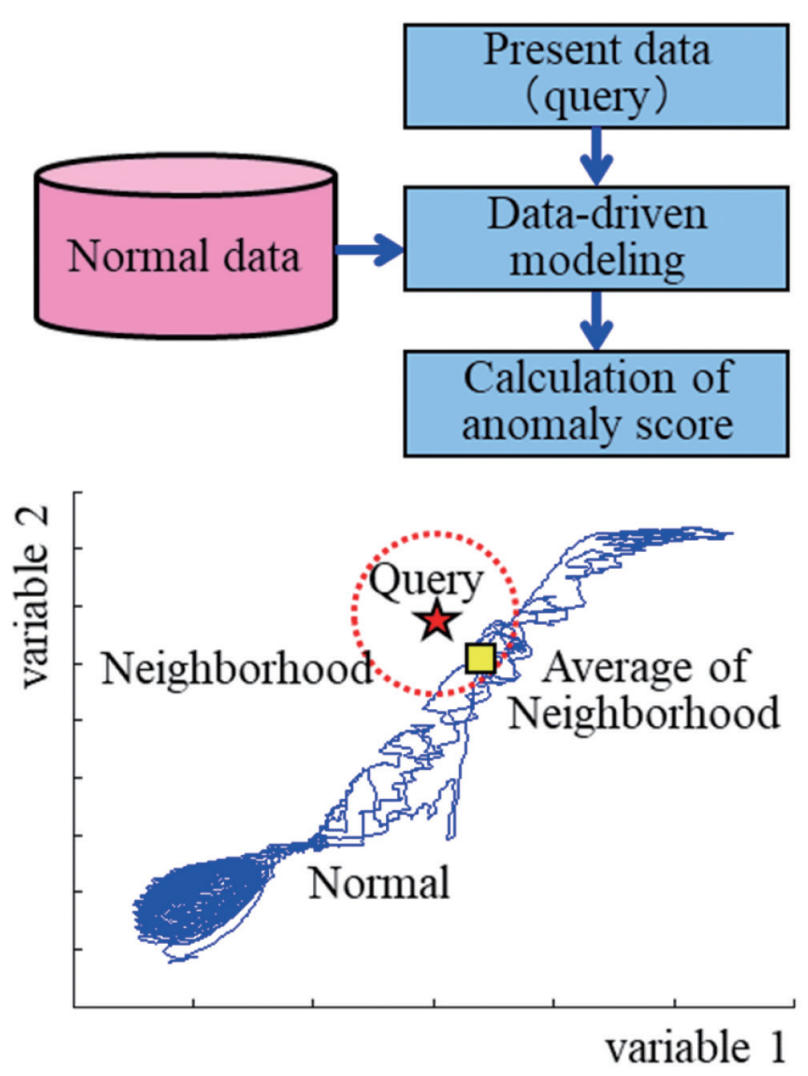

Fig. 12. Application of data-driven modeling method to detecting anomaly signs in a facility. (Online version in color.) 
ことを確認することができる。

\section{5. 異常検知手法の考察}

ここで，レベル別監視の意義について整理する。Fig.1 で 示した階層的な構造を示す設備構成について, 機器レベル は縦方向の視点，全体レベルは横方向の視点での監視とな る。よって, 異常があった時に, 縦横二重の監視が可能で, 総合的判定により要因を特定しやすいという特徴がる。ま た，全体レベル，機器レベルの監視についてはTable 1 に示 す長所, 短所があるので, 全体レベル監視で網羅的に監視 しつつ, 機器レベル監視で重要設備から順次拡大していく という機能分担も可能となる。

\section{AI 要因絞込み技術}

前述の全体レベルの監視では, 異常の発生源が回帰モデ ルを通して他の変数に伝播し結果的に複数の変数で異常が 観測されるという問題がある。説明を容易にするために 6 変数を対象とした事例を Fig. 14 に示す。異常の発生源を $x_{2}$ と仮定した場合， $x_{2}$ を説明変数に有する $x_{1}, x_{4}$ でも異常度 が上昇する。実際には, 変数が百以上あり, 複数の異なる 異常が併発することもあるため, 異常の発生源を特定しが たい。そこで，AIを利用して推定する方法を開発した。

まず, Fig.15に示すように正常時のデータに対して変数 別に微小異常を人工的に付加したときの変数別の異常度パ

Table 1. Comparison of levels between an entire process and facilities

\begin{tabular}{l|c|c}
\hline & Level of an entire process & Level of facilities \\
\hline Detection accuracy & Low & High \\
\hline Ease of modeling & Easy & $\begin{array}{c}\text { Needs individual } \\
\text { modeling }\end{array}$ \\
\hline $\begin{array}{l}\text { Coverage of } \\
\text { monitoring target }\end{array}$ & Large & Small \\
\hline
\end{tabular}

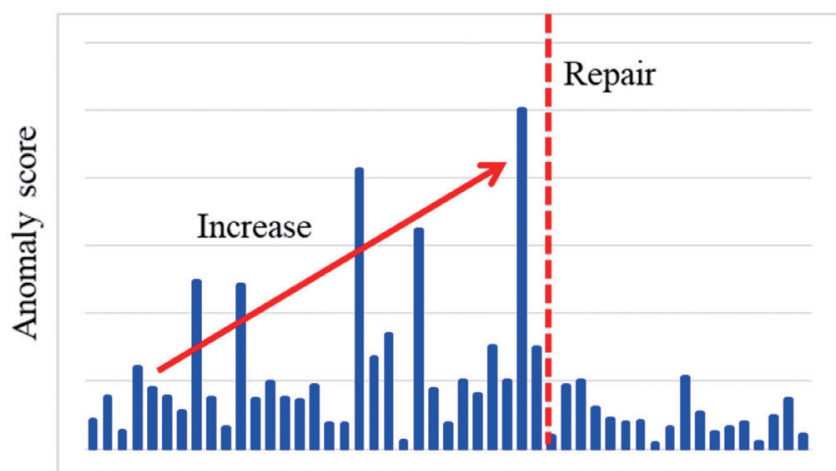

Order of rolling

(a) Principal component analysis
ターン（以下，基本特性パターンと呼ぶ）を準備する。前 述のと打り回帰モデルを通して他の変数に伝搬するため, 基本特性パターンは変数別に異なるパターンを示す。一方 で, 実現象として観測される異常度は基本特性パターンの

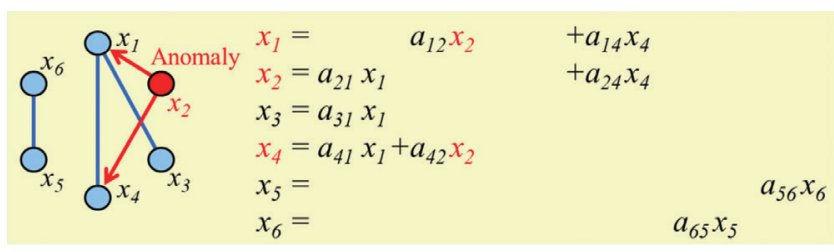

Fig. 14. Image of propagation of anomaly source. (Online version in color.)

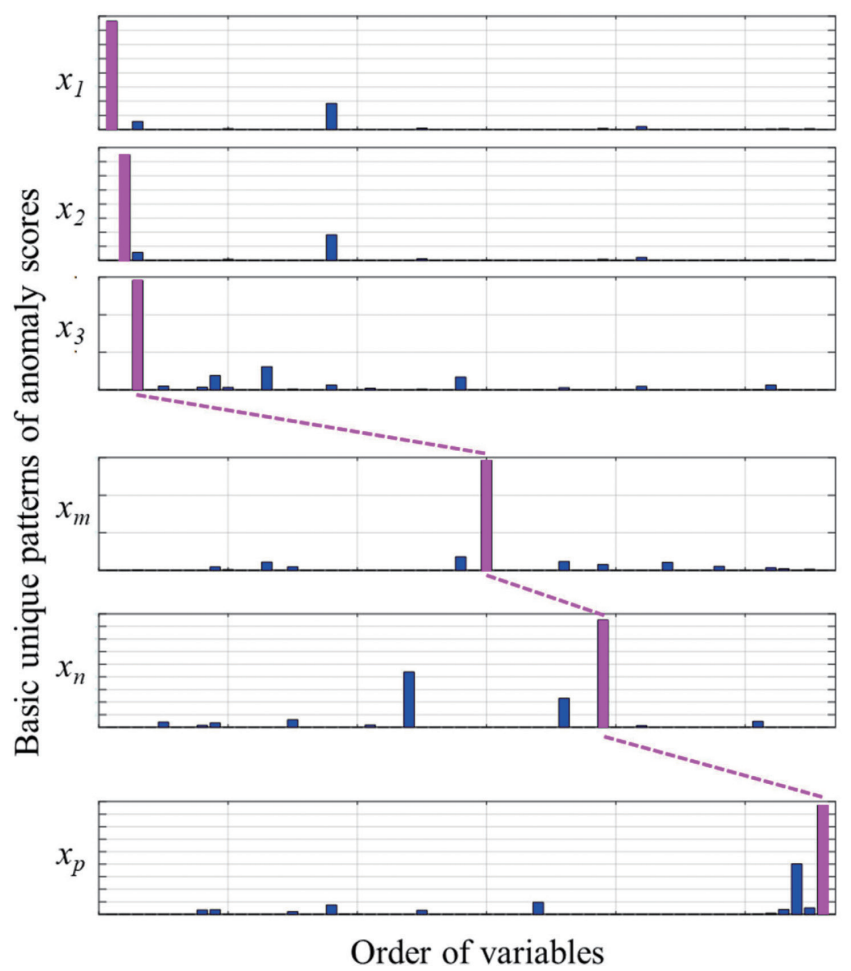

Fig. 15. Basic unique patterns of anomaly scores acquired by adding perturbation to eachvariable. (Online version in color.)

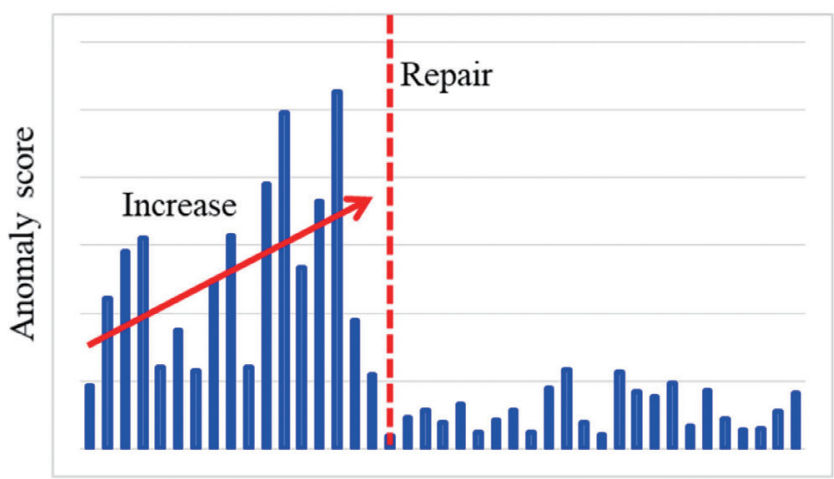

Order of rolling

(b) Data-driven modeling

Fig. 13. Example of detecting anomaly signs by the level of facilities. (Online version in color.) 
線形結合として考えられる。例として $x_{\mathrm{m}}$ と $x_{\mathrm{n}}$ の2つが同時 に発生源となる場合を Fig.16に示す。そこで，予め基本特 性パターンを様々に組合せた合成パターンをディープラー ニングにより学習を行うことで，実現象として観測された 異常度に対して，どの変数の基本特性パターンが含まれて

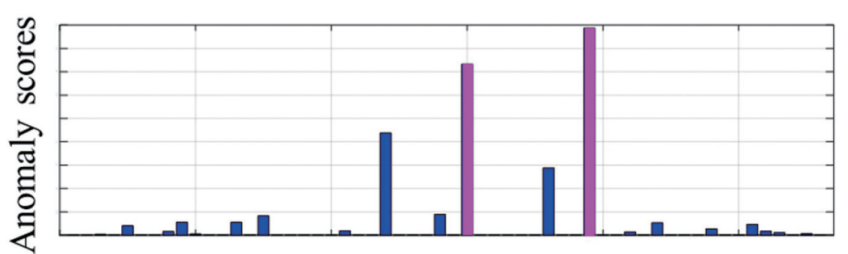

Order of variables

Fig. 16. Case of simultaneous occurrence of anomalies. (Online version in color.)

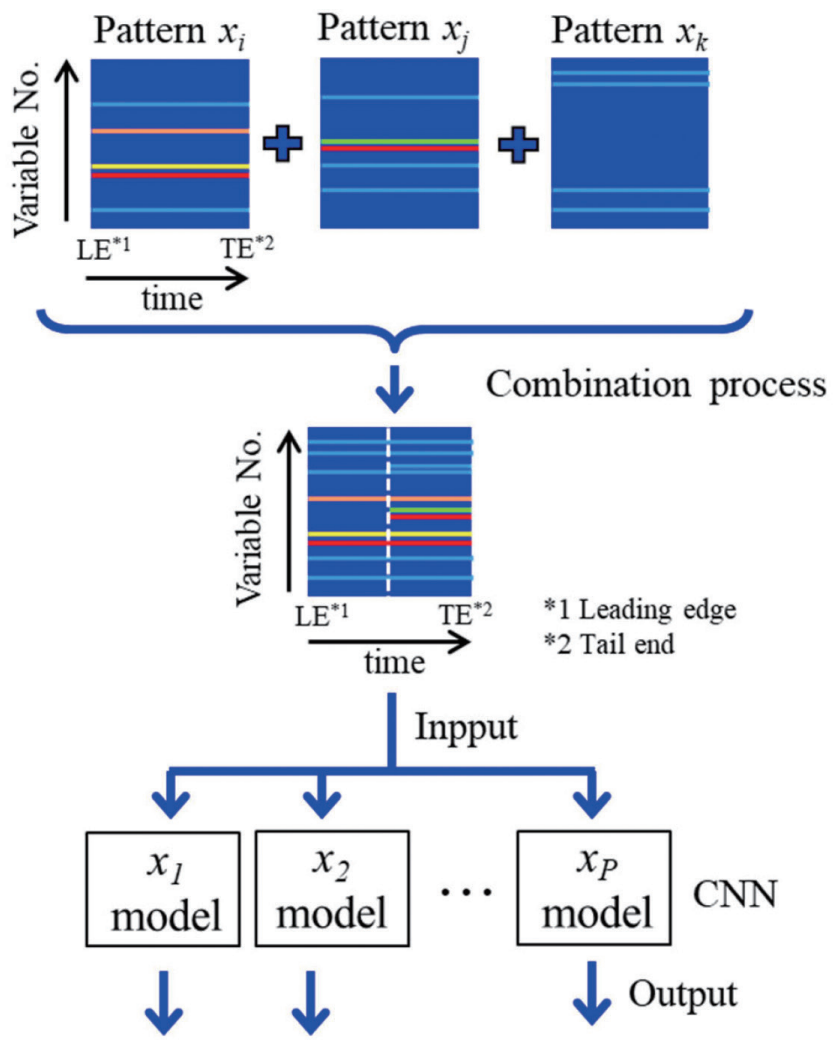

Each pattern $x_{1}, x_{2}, \cdots, x_{P}$ included ?

(Yes? / No?)

Fig. 17. Learning procedure for a combination of basic unique patterns. (Online version in color.)
いるかを推定することにより, 発生源の異常変数を絞り込 むことができる。

実際には, 圧延材 1 本分の基本特性パターンを変数 $\times$ 時 間の 2 次元画像として準備し, 後述する方法で人工的に合 成した大量のサンプルを2次元画像として扱うことによ り，畳み込み層とプーリング層のセットが2段階で構成さ れる畕み込みニューラルネット $(\mathrm{CNN})^{22-26)}$ を適用した学 習を行った。ただし，変数の並び順の影響を排除するため に，各層のフィルタは時間軸方向だけに作用するものとし た。合成にあたっては, 変数の組合せ, 重みだけでなく, 圧 延材の先端から微小異常を付与する場合, 中間部から付 与する場合など様々な組合せをランダムに行った。また， $\mathrm{CNN}$ モデルは基本特性パターン別に準備し, 対応する基本 特性パターンが含まれるかどうかを判定する。パターン別 にモデルを準備した大きな理由は, 将来, 変数を増加させ たときにモデルのメンテナンスが容易となるためである。 学習の概要を Fig.17, 詳細を Table 2に示す。なお, Fig.17で 示したものは，基本特性パターン $x_{\mathrm{i}}$ と $x_{\mathrm{k}}$ は先端（LE）から, $x_{\mathrm{j}}$ は中央から微小異常を付与したものを合成したイメージ である。

$$
\begin{aligned}
& \text { 変数 } \mathrm{i} \text { の学習データ }= \\
& w_{1} \times \text { 変数 } \mathrm{i} \text { 基本特性パターン } \\
& +w_{2} \times \text { その他変数 } 1 \text { の基本特性パターン } \\
& +w_{3} \times \text { その他変数 } 2 \text { の基本特性パターン } \\
& +\cdot \cdot \cdot+\text { イズ } \\
& w_{1}, w_{2}, \cdots \cdot \text { : 重み }
\end{aligned}
$$

過去発生した5つのトラブルに対する推定結果を Table 3 に示す。異常度があらかじめ設定した閾值を超えた变数の数 に対する発生源として推定した変数の数の比率を集約率と

Table 2. Training conditions

\begin{tabular}{l|c}
\hline $\begin{array}{l}\text { Number of basic unique patterns (Number of variables } \\
\text { selected for anomaly source estimation) }\end{array}$ & 95 \\
\hline Number of training data per basic unique pattern & 14,000 \\
\hline Maximum number of patterns to combine & 4 \\
\hline $\begin{array}{l}\text { How to determine the parameters such as weights } \\
\text { given to the pattern and the positions to be combined }\end{array}$ & random \\
\hline Type of learning model & CNN (95 models) \\
\hline
\end{tabular}

Table 3. Result of AI estimation

\begin{tabular}{l|c|c|c|c|c}
\hline & Fault A & Fault B & Fault C & Fault D & Fault E \\
\hline $\begin{array}{l}\text { Number of variables whose anomaly } \\
\text { score exceeded the threshold }\end{array}$ & 45 & 15 & 39 & 17 & 10 \\
\hline $\begin{array}{l}\text { Number of variables estimated as } \\
\text { anomaly sources }\end{array}$ & 3 & 5 & 5 & 3 & 3 \\
\hline $\begin{array}{l}\text { Number of missed variables that } \\
\text { must be detected }\end{array}$ & 0 & 0 & 0 & 0 & 0 \\
\hline $\begin{array}{l}\text { Number of variables not valid as } \\
\text { anomaly sources }\end{array}$ & 0 & 3 & 3 & 0 & 1
\end{tabular}


すると, 集約率は7〜33\%という結果を得た。また, 絞り込み 後の変数は, トラブルの分析から判断される検知すべき変数 について見逃しはないため, 推定結果は妥当と言える。

\section{7. 結言}

データサイエンス技術を適用した鉄鋼プロセス設備のレ ベル別異常予兆監視技術について, 開発したシステムの概 要や適用した検知手法を論じた。階層構造を示す各機器・ 設備に対して，プロセス全体, 機器, 計器のレベル別監視 を構成し，各レベルに適切な解析手法を適用することによ り, 網羅的かつ検知精度の高い異常予兆監視を可能とする システムを開発した。また，膨大な監視点数に対して効率 的な監視を可能とするため，異常度をヒートマップ表示す る仕組みを開発した。本機による熱間圧延工場ラインでの 監視では，トラブル未然防止に繋がる結果を得ることがで きた。

\section{文献}

1) T.Yamamoto, K.Wada, S.Kanoko and A.Higuchi: Shinnittetsu Sumikin Giho, 402(2015), 2 (in Japanese).

2 ) T.Naruse, S.Midorikawa and S.Takata: JFE Tech. Rep., 17(2012), 1.

3 ) Y.Akechi, S.Midorikawa and S.Kobayashi: JFE Tech. Rep., 17(2012), 17

4 ) A.Kitamura, M.Nakayama, M.Konishi and J.Yabumoto: Trans. Inst. Syst. Control Inf. Eng., 4(1991), 235 (in Japanese).

5 ) N.Nozaki: CAMP-ISIJ, 23(2010), 203, CD-ROM (in Japanese).

6 ) T.Naruse, M.Takada, T.Hirata, Y.Hagio and Y.Akechi: Tribologist, 62(2017), 671 (in Japanese).
7 ) T.Hirata, Y.Hachiya and N.Suzuki: JFE Tech. Rep., 26(2021), 15.

8 ) T.Hirata, Y.Kawahara, M.Sugiyama and K.Asano: IFACPapersOnLine, 48(2015), No.21, 871.

9 ) T.Hirata and D.Takahashi: CAMP-ISIJ, 30(2017), 289, CD-ROM (in Japanese).

10) R.Tibshirani: J. R. Stat. Soc. B Methodol., 58(1996), 267.

11) N.Meinshausen and P.Bühlmann: Ann. Stat., 34(2006), 1436.

12) T.Ide, A.C.Lozano, N.Abe and Y.Liu: Proc. 2009 SIAM Int. Conf. on Data Mining (SDM), SIAM, Philadelphia, PA, (2009), 97.

13) S.Chen, M.Peng, H.Xiong and S.Wu: Cluster Comput., 22(2019), 5407.

14) J.E.Jackson and G.S.Mudholkar: Technometrics, 21(1979), 341.

15) J.E.Jackson: J. Qual. Technol., 12(1980), 201.

16) J.V.Kresta, J.F.MacGregor and T.E.Marlin: Can. J. Chem. Eng., 69(1991), 35.

17) T.Yamamoto, A.Shimameguri, M.Ogawa, I.Hashimoto and M.Kano: IFAC Proc. Vol., 37(2004), No.1, 379.

18) M.Ito, S.Matsuzaki, H.Ogai, N.Odate, K.Uchida, S.Saito and N.Sasaki: Tetsu-to-Hagané, 90(2004), 917 (in Japanese).

19) M.Kishi, K.Kimura, J.Ohata and S.Yamamoto: IFAC Proc. Vol., 37(2004), No.15, 447.

20) H.Shigemori, M.Kano and S.Hasebe: J. Process Control, 21(2011), 293.

21) H.Shigemori: IFAC Proc. Vol., 45(2012), No.23, 234.

22) Y.LeCun, B.Boser, J.S.Denker, D.Henderson, R.E.Howard, W.Hubbard and L.D.Jackel: Neural Comput., 1(1989), 541.

23) Y.LeCun, L.Bottou, Y.Bengio and P.Haffner: Proc. IEEE, 86(1998), 2278.

24) G.E.Hinton, S.Osindero and Y.W.Teh: Neural Comput., 18(2006), 1527.

25) A.Krizhevsky, I.Sutskever and G.E.Hinton: Advances in Neural Information Processing Systems 25, NIPS, (2012), 1097.

26) L.Wen, L.Gao, X.Li, M.Xie and G.Li: 2017 IEEE Int. Conf. on Industrial Engineering and Engineering Management (IEEM 2017), IEEE, Piscataway, NJ, (2017), 813. 